\title{
PENGARUH ELEMEN EKUITAS MEREK TERHADAP KEPUTUSAN PEMBELIAN DI GERAI STARBUCKS COFFEE (Studi Pada Konsumen Domestik Starbucks Coffee di Wilayah Bali)
}

\author{
Vania Dwi Alfiana Putri ${ }^{1}$ \\ I Gusti Agung Ketut Gede Suasana ${ }^{2}$
}

${ }^{1,2}$ Fakultas Ekonomi dan Bisnis Universitas Udayana (Unud), Bali, Indonesia email :Vaniaalfiana94@gmail.com

\begin{abstract}
ABSTRAK
Tujuan dari penelitian ini adalah untuk mengetahui pengaruh elemen ekuitas merek terhadap keputusan pembelian dari coffee shop merek Starbucks Coffee. Jumlah sampel yang diambil sebanyak 100 responden yang diambil dari beberapa gerai yang berada di wilayah Bali, dengan metode non probability sampling. Pengumpulan data dilakukan melalui penyebaran kuisioner. Teknik analisis yang digunakan adalah regresi berganda. Berdasarkan hasil penelitian maka disarankan agar pihak manajemen dan departemen pemasaran perusahaan khususnya dari perusahaan pemilik merek Starbucks Coffee untuk tetap mempertahankan variabel ekuitas merek yang ada agar dapat meningkatkan keputusan pembelian terhadap merek Starbucks Coffee.
\end{abstract}

Kata kunci: ekuitas merek, keputusan pembelian

\begin{abstract}
The purpose of this study is to determine the effect of brand equity elements on purchasing decisions from the coffee shop brand Starbucks Coffee. The number of samples taken as many as 100 respondents taken from several outlets located in the area of Bali, with the method of non-probability sampling. Data collection was done through questionnaire distribution. The analysis technique used is multiple regression. Based on the results of research, it is suggested that the management and marketing department of the company especially from the company brand Starbucks Coffee to maintain the existing brand equity variables in order to improve purchasing decisions on the brand Starbucks Coffee.
\end{abstract}

Keywords: brand equity, purchasing decision 


\section{PENDAHULUAN}

Perkembangan jaman masyarakat kota pada saat ini telah mengalami perubahan gaya hidup (lifestyle). Gaya hidup urban yang digandrungi saat ini adalah kebiasaan kelompok masyarakat tertentu yang gemar berkumpul di cafe atau coffee shop, hal ini didukung oleh pendapatRhenald Kasali (2010 : 27), seorang pakar di bidang pemasaran yang mengatakan bahwa saat ini ngopi kini bukan lagi sekedar untuk menghilangkan rasa kantuk, tapi sebagai bagian dari gaya hidup, dimana coffee shop menjadi tempat berkumpul yang amat diminati”.

Persaingan perusahaan untuk memperebutkan konsumen saat ini tidak lagi terbatas pada atribut fungsional produk seperti kegunaan produk saja, melainkan sudah dikaitkan dengan merek yang mampu memberikan citra khusus bagi pemakainya, dengan kata lain peranan merek mengalami pergeseran. Menurut Winatapradja (2013) pada tingkat persaingan yang rendah, merek hanya sekedar membedakan antar satu produk dengan produk lainnya, sedangkan pada tingkat persaingan yang tinggi merek memberikan kontribusi dalam menciptakan dan menjaga daya saing sebuah produk. Merek akan dihubungkan dengan citra khusus yang mampu memberikan asosiasi tertentu dalam benak konsumen.

Starbucks Corporation adalah kedai kopi global asal Amerika Serikat yang berkantor pusat di Seattle, Washington (www.wikipedia.org/wiki/starbucks, diakses pada Tanggal 13 Februari 2017). Di Indonesia, PT. Sari Coffee Indonesia merupakan pemegang lisensi utama Starbucks Coffee Internasional dan membuka toko pertamanya di Plaza Indonesia pada Tanggal 17 Mei 2002. Berdasarkan hasil wawancara dengan Ekantara, selaku salah satu Senior Barista yang sudah 
menyandang gelar Coffee Master dan sudah 4 Tahun bekerja di salah satu gerai Starbucks Coffee di Bali menyatakan bahwa Starbucks Coffee merupakan coffee shop yang memiliki jumlah gerai terbanyak di Bali dibandingkan dengan coffee shop lainnya yang sejenis, seperti Excelso, J.co, Coffee Bean, dan sebagainya dengan total yaitu 23 gerai dimana dua diantaranya berada di Tabanan dan Gianyar, sedangkan sisanya tersebar di Denpasar dan Badung.

Fenomena maraknya bisnis di industri food and beverages juga tak luput dari Bali, berdasarkan informasi yang diperoleh dari situs Dinas Pariwisata Provinsi Bali, pada Tahun 2016 terdapat lebih dari 376 industri food and beverages yang terdaftar dan tersebar di Denpasar, data tersebut belum termasuk industri food and beveragesyang berada di luar wilayah Denpasar seperti Badung, Gianyar, dan sebagainya. (www.disparda.baliprov.go.id diakses pada Tanggal 13 Februari 2017). Industri food and beverages yang menjamur dan tersebar di berbagai wilayah di Provinsi Bali tentunya membuat masyarakat dapat dengan mudah menemui beragam jenis coffee shop di Bali, mulai dari brand lokal hingga brand yang sudah mendunia.

Menurut Kartajaya (2010:62), mendefinisikan merek sebagai aset yang menciptakan nilai bagi pelanggan dengan meningkatkan kepuasan dan menghargai kualitas. Merek-merek tersebut bersaing dalam benak konsumen untuk menjadi yang terbaik.Ekuitas merek merupakan aset yang dapat memberikan nilai tersendiri di mata pelanggannya. Aktivitas konsumen dalam pembelajaran dan proses keputusan pembeliannya dapat membentuk dan mendorong terbentuknya ekuitas merek. Dengan kata lain sumber ekuitas merek 
adalah ketika konsumen menyadari keberadaan merek dan memiliki asosiasi merek yang unik, kuat, dan cenderung positif (Nursanti, 2017). Menjaga nama baik merek adalah hal penting karena sukses tidaknya pengembangan merek sangat tergantung pada pengetahuan dan pemahaman konsumen tentang merek itu sendiri (Adriana, 2017). Kekuatan merek yang beredar di pasaran dapat diketahui dengan melakukan riset yang berguna untuk mengukur kekuatan merek atau ekuitas merek (Putra, 2014).

Perusahaan akan berhasil memperoleh konsumen dalam jumlah yang banyak apabila dinilai dapat memberikan kepuasan bagi konsumen. Terciptanya kepuasan konsumen dapat memberikan beberapa manfaat, diantaranya hubungan antara perusahaan dan konsumen menjadi harmonis, memberikan dasar yang baik bagi pembelian ulang, membentuk rekomendasi dari mulut ke mulut yang menguntungkan perusahaan dan terciptanya loyalitas konsumen, Firdaus (2015). Ekuitas merek memegang peranan kunci terhadap psikologis seorang pelanggan dalam pembentukan persepsi dan pembangunan karakter pelanggan. Keputusan pembelian melibatkan keyakinan pelanggan pada suatu merek sehingga timbul rasa percaya atas kebenaran tindakan yang diambil (Suharyani, 2015).

Berdasarkan paparan yang telah dijelaskan sebelumnya, maka peneliti tertarik untuk melakukan penelitian terhadap konsumen domestik dari Starbucks Coffee karena coffee shop tersebut merupakan salah satu merek internasional yang hingga saat ini mampu bertahan di Indonesia meskipun saat ini sudah banyak kedai kopi lokal dengan kualitas yang cukup baik dan memiliki harga yang jauh lebih murah dibanding Starbucks Coffee, selain itu brand tersebut juga salah satu 
brand yang memiliki gerai terbanyak dibandingkan coffee shop lainnya yang sejenis, sehingga peneliti ingin mengetahui faktor apa saja yang mempengaruhi konsumen domestik untuk tetap melakukan keputusan pembelian di Starbucks Coffee. Penelitian ini berusaha untuk melakukan kajian terhadap pengaruh elemen ekuitas merek terhadap keputusan pembelian konsumen untuk membeli produk dari gerai kopi tersebut.

Berdasarkan pada latar belakang tersebut di atas, maka masalah pokok yang dikemukakan dalam penelitian ini adalah: 1) Bagaimana pengaruh kesadaran merek terhadap keputusan pembelian di Starbucks Coffee? 2) Bagaimana pengaruh persepsi kualitas terhadap keputusan pembelian di Starbucks Coffee? 3) Bagaimana pengaruh asosiasi merekterhadap keputusan pembelian di Starbucks Coffee? 4) Bagaimana pengaruh loyalitas merek terhadap keputusan pembelian di Starbucks Coffee?

Berdasarkan rumusan masalah yang dipaparkan di atas, maka dapat diketahui tujuan dilakukannya penelitian ini adalah: 1) Untuk menjelaskan pengaruh kesadaran merekterhadap keputusan pembelian di Starbucks Coffee. 2) Untuk menjelaskan pengaruh persepsi kualitas terhadap keputusan pembelian di Starbucks Coffee. 3) Untuk menjelaskan pengaruh asosiasi merek terhadap keputusan pembelian di Starbucks Coffee. 4) Untuk menjelaskan pengaruh loyalitas merekterhadap keputusan pembelian di Starbucks Coffee.

Ekuitas merek harus selalu dijaga keberadaannya agar produk tetap di benak pelanggan yang tersalurkan dengan adanya keputusan pembelian (Nigam \& Kausik, 2011). Ekuitas merek dapat membuat produk lebih berbeda dengan merek 
lainnya, lebih dikenal konsumen dan lebih mendapat respon yang baik dari konsumen (Norouzi, 2011). Semakin kuat ekuitas merek suatu produk, maka akan semakin kuat pula daya tariknya bagi konsumen untuk membeli produk tersebut dan pada akhirnya akan memberikan keuntungan yang terus meningkat kepada perusahaan (Lee \& Leh, 2011). Merek yang sukses memberikan keunggulan kompetitif yang sangat penting untuk keberhasilan perusahaan (Fayrene YL, 2011).

Brand awareness (kesadaran merek), konsumen lebih cenderung memilih merek yang sudah dikenalnya karena mereka merasa aman menggunakan merek yang lebih dikenalnya. Merek yang terkenal lebih menarik banyak perhatian dibanding yang tidak, umumnya karena merek tersebut dikenal dan bisa dipercaya.

Brand asociation (asosiasi merek), asosiasi merek menginterpretasikan nilai yang dijanjikan oleh suatu brand. Asosiasi merek yang kuat memberi citra yang kuat pula terhadap suatu brand. Brand yang selalu konsisten tehadap nilai yang dijanjikan akan memiliki citra yang positif di mata konsumen. Pada akhirnya brand tesebutlah yang akan dipilih oleh konsumen.

Perceived Quality (persepsi kualitas), persepsi kualitas tiap-tiap konsumen terhadap merek suatu produk akan berbeda-beda. Pengalaman selama menggunakan suatu brand akan memberikan persepsi yang berbeda-beda. Konsumen akan lebih condong terhadap merek yang mereka tahu akan memberikan standar kualitas yang tinggi. 
Brand loyalty (loyalitas merek), konsumen akan membandingkan nilai yang ditawarkan suatu merek produk tertentu, dan apabila telah merasakan kepuasan atas nilai yang diberikan, konsumen akan memilih untuk loyal terhadap merek tersebut.

Menurut Asif et al (2015), kesadaran merek merupakan suatu kondisi dimana konsumen akrab dengan suatu merek dan dapat dengan mudah mengingat beberapa hal yang menguntungkan, kuat, dan unik dari sebuah asosiasi merek. Peran brand awareness dalam keseluruhan brand equity tergantung dari sejauh mana tingkatan kesadaran yang dicapai oleh suatu merek. Kesadaran merek berarti bahwa orang tahu tentang produk danmemiliki ide yang tepat mengenai penggunaan produk (Ahmad et al, 2014). Kesadaran merek membutuhkan continum ranging (jangkauan kontinum) dari perasaan yang tidak pasti bahwa merek tertentu telah dikenal dan menjadi keyakinan bahwa produk tersebut merupakan satusatunya dalam kelas produk yang berada pada kategorinya (Muzaqqi, dkk 2016). Persepsi kualitas merupakan faktor yang menjadi alasan mengapa sebah merek dipertimbangkan dan dibeli. Hal ini sangat mempengaruhi merek apa yang akan dipilih oleh pelanggan untuk selanjutnya dapat mengambil keputusan untuk melakukan pembelian terhadap suatu merek tersebut (Yaseen $e t$ al, 2011). Persepsi konsumen mengenai keseluruhan kualitas suatu produk atau jasa mampu mempengaruhi kosumen tersebut di dalam melakukan keputusan pembelian. Hal tersebut dapat dilihat dari nilai persepsi kualitas sebagai alasan konsumen untuk membeli suatu produk (Moradi \& Zarei, 2011). Miftakh (2013) mengatakan persepsi kualitas merupakan persepsi pelanggan terhadap keseluruhan 
kualitas atau keunggulan suatu produk atau jasa layanan berkaitan dengan apa yang diharapkan oleh pelanggan. Kredibilitas merek memiliki pengaruh yang kuat terhadap asosiasi merek dibandingkan dengan kesadaran merek, hal ini dikarenakan persepsi kepercayaan individual para konsumen cenderung lebih mengarah pada suatu merek yang tidak asing dan kemudian menimbulkan asosiasi merek di benak konsumen (Chen, 2013).

Menurut French dan Smith (2013), untuk setiap merek tertentu, asosiasi merek suatu perusahaan merupakan inti untuk pengambilan keputusan, sebagian konsumen menggunakannya untuk membantu proses, mengatur dan mengambil informasi dalam ingatan konsumen dan untuk membantu mereka dalam menentukan keputusan pembelian. Asosiasi merek mencerminkan pencitraan suatu merek terhadap suatu kesan tertentu dalam kaitannya dengan kebiasaan, gaya hidup, manfaat, atribut, produk, geografis, harga, pesaing, selebritis/seseorang dan lain-lainnya (Negara, dkk 2013). Menurut Fouladivanda et al. (2013) mengatakan bahwa asosiasi merek (brand association) adalah suatu konsep hubungan yang rumit satu sama lain, yang terdiri dari beberapa ide, episode, contoh, dan fakta yang membuat jaringan pengetahuan atas merek pada ingatan konsumen. Perlu diketahui bahwa asosiasi merek merupakan faktor kunci yang dapat mendorong pengembangan suatu merek, hal ini dikarenakan asosiasi merek yang baik secara tidak langsung dapat membuat pelanggan menjadi loyal terhadap merek dan dapat menimbulkan efektivitas merek dari mulut ke mulut (word of mouth) (Wang, 2015). Malik et al (2013) berpendapat bahwa loyalitas merek dapat didefinisikan sebagai tingkat keeratan pelanggan terhadap merek 
tertentu, yang diungkapkan melalui pembelian ulang yang terlepas dari pemasaran yang diciptakan oleh merek pesaing. Sedangkan menurut Bastian (2014), loyalitas merek adalah sebuah komitmen yang kuat dalam berlangganan atau membeli suatu merek secara konsisten di masa yang akan datang. Menurut Sari (2016), tingkat yang paling dasar adalah pembeli tidak loyal atau sama sekali tidak tertarik pada merek-merek yang ditawarkan. Dengan demikian merek memainkan peran yang kecil dalam keputusan pembelian. Pada umumnya jenis konsumen ini suka berpindah-pindah merek atau biasa disebut konsumen switcher atau price buyer yang lebih mementingkan harga dibanding merek. Yang kedua adalah pembeli yang merasa puas dengan produkyang digunakan, atau minimal tidak mengalami kekecewaan. Pada dasarnya tidak terdapat dimensi ketidakpuasan yang cukup memadai untuk mendorong suatu perubahan. Para pembeli ini disebut habitual buyer. Ketiga adalah pembeli yang puas, namun memikul biaya peralihan (switching cost) baik dalam waktu, uang, atau resiko sehubungan dengan upaya untuk melakukan pergantian ke merek lain. Pembeli ini biasa disebut statisfied buyer. Yang keempat merupakan konsumen yang benarbenar menyukai merek tersebut. Pilihan konsumen terhadap suatu merek dilandasi pada suatu asosiasi, seperti simbol, pengalaman menggunakan, atau kesan kualitas yang tinggi. Pembeli ini disebut sahabat merek, karena terdapat perasaan emosional dalam menyukai merek.

Tingkat teratas adalah para pelanggan setia. Para pelanggan mempunyai suatu kebanggaan dalam menemukan atau menjadi pengguna suatu merek. Merek 
tersebut sangat penting bagi pelanggan baik dari segi fungsi, maupun ekspresi. Pembeli ini disebut commited buyers.

Doostar et al. (2012) menyatakan untuk membuat konsumen mengambil keputusan dalam membeli produk, pemasar harus membangun merek yang kuat dengan membentuk konsep yang berbeda dengan produk yang mereka jual. Keputusan membeli atau tidak membeli merupakan bagian dari unsur yang melekat pada diri individu konsumen yang disebut behavior dimana ia merujuk kepada tindakan fisik yang nyata dapat dilihat dan diukur oleh orang lain (Nitisusastro, 2012:78). Dalam memahami perilaku konsumen, terdapat banyak pengaruh yang mendasari seseorang dalam mengambil keputusan pembelian suatu produk atau merek. Pada kebanyakan orang, perilaku pembeli konsumen seringkali diawali dan di pengaruhi oleh banyak rangsangan (stimuli) dari luar dirinya, baik berupa rangsangan pemasaran maupun rangsangan dari lingkungan yang lain. Rangsangan tersebut diproses (diolah) dalam diri, sesuai dengan karakteristik pribadinya, sebelum akhirnya diambil keputusan pembelian (Pratama, 2017).

Kesadaran merek adalah kemampuan dari pelanggan potensial untuk mengenali atau mengingat bahwa suatu merek termasuk ke dalam kategori produk tertentu. Penelitian yang dilakukan oleh Siali (2016) yang menunjukkan bahwa kesadaran merek memiliki hubungan yang signifikan dengan keputusan pembelian konsumen dalam merek internasional alas kaki. Penelitian yang dilakukan oleh Akhtar et al (2015) juga menunjukkan bahwa hasil dari variabel brand awareness menunjukkan hasil yang dapat diandalkan. Winatapradja (2013) 
menyatakan hasil penelitiannya menemukan bahwa kesadaran merek (brand awareness) berpengaruh positif dan signifikan terhadap keputusan pembelian. Berdasarkan teori dan uraian tersebut, maka dapat disimpulkan hipotesis sebagai berikut:

$\mathrm{H}_{1}$ : Kesadaran merek (brand awareness) berpengaruh positif terhadap keputusan pembelian.

Penelitian yang dilakukan oleh Tarmedi dan Penty (2009) mengenai Pengaruh perceived quality dari brand equity (X) terhadap keputusan pembelian (Y) mendapatkan bahwa koefisien korelasi antara variabel perceived quality dari brand equity terhadap variabel keputusan pembelian produk memiliki pengaruh yang positif dan signifikan. Penelitian Widhiarta (2015) menunjukkan bahwa persepsi kualitas berpengaruh positif terhadap keputusan pembelian dikarenakan persepsi kualitas dapat mempengaruhi seseorang dalam membuat keputusan pembelian seperti desain yang menarik, kualitas yang baik dan mudah dalam pengoperasiannya. Penelitian yang dilakukan oleh Astuti dan Cahyadi (2007) menemukan bukti bahwa kualitas persepsi mempunyai pengaruh terhadap keputusan pembelian. Berdasarkan teori dan uraian tersebut, maka dapat disimpulkan hipotesis sebagai berikut:

$\mathrm{H}_{2}$ : Persepsi kualitas (perceived quality) berpengaruh positif terhadap keputusan pembelian.

Penelitian yang dilakukan oleh Winatapradja (2013) menegenai keputusan pembelian produk Donat J.Co\& Coffee menemukan bahwa asosiasi merek memiliki pengaruh yang positif dan signifikan terhadap keputusan pembelian. 
Penelitian Rahendy (2014) mengatakan variabel asosiasi merek mempunyai pengaruh terhadap keputusan pembelian handphone Samsung Android adalah terbukti. Begitu pula dengan hasil penelitian Fadli dan Qamariah (2008) yang menyatakan bahwa asosiasi merek berpengaruh signifikan terhadap keputusan pembelian. Berdasarkan teori dan uraian tersebut, maka dapat disimpulkan hipotesis sebagai berikut:

$\mathrm{H}_{3}$ : Asosiasi merek (brand association) berpengaruh positif keputusan pembelian.

Penelitian dari Rahendy (2014) mengatakan bahwa pengaruh loyalitas konsumen terhadap keputusan pembelian handphone Samsung Android adalah signifikan. Sedangkan hasil dari pengujian Subianto (2013), hipotesis secara parsial (individu) yang pengujiannya menggunakan variabel loyalitas merek (X) terhadap keputusan pembelian (Y) telah menghasilkan pengaruh yang positif dan signifikan. Wijaya (2011) yang juga menyatakan bahwa loyalitas merek berpengaruh positif dan signifikan. Hasil tersebut diperkuat dengan loyalitas memungkinkan proses pembelian yang berulang. Berdasarkan teori dan uraian tersebut, maka dapat disimpulkan hipotesis sebagai berikut:

$\mathrm{H}_{4}$ : Loyalitas merek (brand loyalty) berpengaruh positif terhadap keputusan pembelian. 


\section{Gambar 1. Kerangka Konsep}

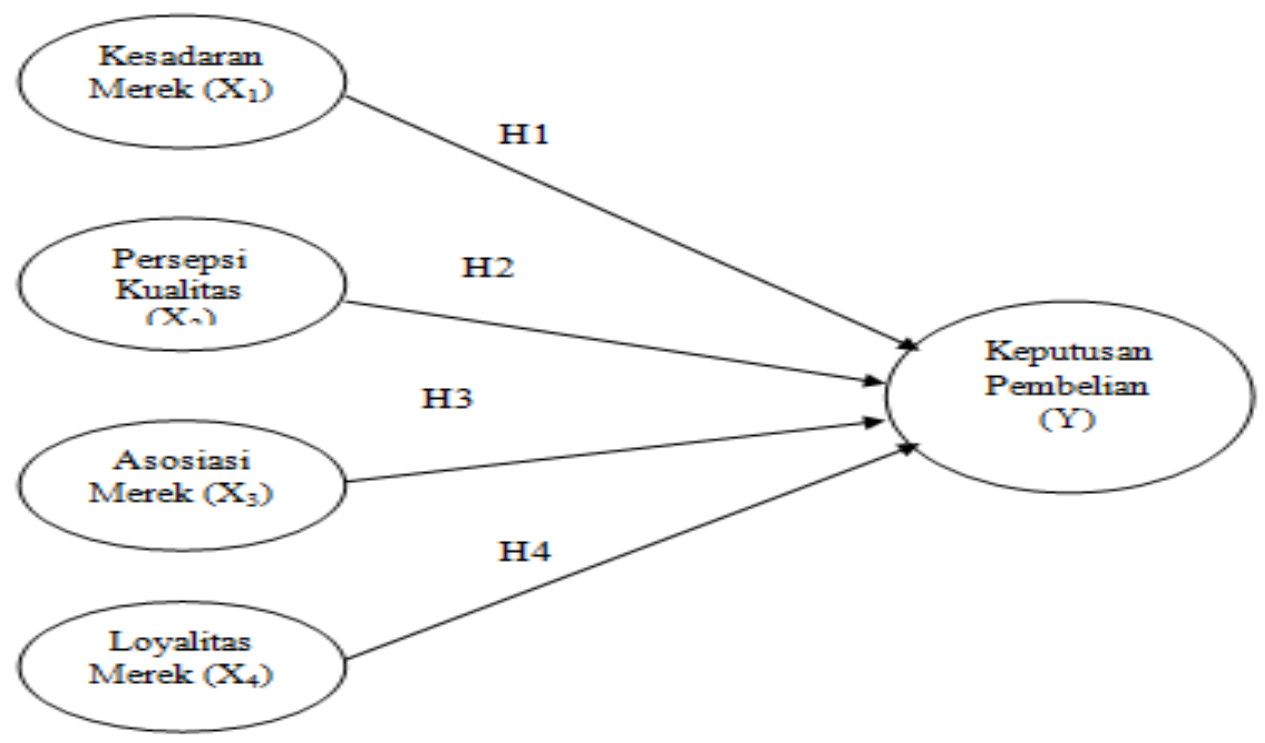

Sumber : Data primer diolah, 2017

\section{METODE PENELITIAN}

Desain penelitian yang digunakan disini adalah penelitian asosiatif, hal ini dikarenakan variabel-variabel tersebut diperkirakan akan memiliki hubungan antara satu dengan yang lainnya.

Penelitian ini dilakukan di seputar wilayah Kabupaten Denpasar dan Badung, dimana di wilayah tersebut merupakan tempat tersebarnya gerai Starbucks Coffee serta kawasan yang padat aktivitas masyarakat baik untuk sekolah, bekerja, maupun bepergian. Selain sebagai kota yang cukup padat penduduk karena sebagai pusat segala aktivitas, terdapat juga beberapa mall atau pusat berbelanjaan yang di dalamnya terdapat gerai Starbucks Coffee sehingga memudahkan peneliti untuk melihat dan mengamati bagaimana perilaku yang dicerminkan oleh konsumen dalam mengambil keputusan untuk membeli produk 
dari Starbucks Coffee tersebut.Subjek dalam penelitian ini adalah customer domestik dari Starbucks Coffee yang tersebar di beberapa wilayah Denpasar dan Badung. Objek dalam penelitian ini adalah perilaku konsumen mengenai pengambilan keputusan pembelian di coffee shop tersebut.

\section{Tabel 1. indikator variabel}

\begin{tabular}{|c|c|c|}
\hline Variabel Penelitian & Indikator & Referensi \\
\hline Kesadaran merek $\left(\mathrm{X}_{1}\right)$ & $\begin{array}{ll}\text { 1. } & \text { Mengenali merek } \\
\text { 2. } & \text { Mengingat merek } \\
\text { 3. } & \text { Ciri khas } \\
\text { 4. } & \text { Mengenali varian }\end{array}$ & $\begin{array}{l}\text { Humdiana (2005) } \\
\text { dan Suprapti (2010) }\end{array}$ \\
\hline Persepsi kualitas $\left(\mathrm{X}_{2}\right)$ & $\begin{array}{ll}\text { 1. } & \text { Kualitas } \\
\text { 2. } & \text { Kehandalan } \\
\text { 3. } & \text { Daya tahan } \\
\end{array}$ & $\begin{array}{lr}\text { Negara } & (2013), \\
\text { Sudarsono dan } & \text { durniawati } \\
\text { Kurnal }\end{array}$ \\
\hline Asosiasi merek $\left(\mathrm{X}_{3}\right)$ & $\begin{array}{ll}\text { 1. } & \text { Manfaat } \\
\text { 2. } & \text { Gaya hidup } \\
\text { 3. } & \text { Kredibilitas } \\
\text { 4. } & \text { Produk inovatif } \\
\text { 5. } & \text { Citra merek }\end{array}$ & $\begin{array}{lr}\text { Humdiana } & (2005) \\
\text { dan } & \text { Kurniawan } \\
(2010) & \end{array}$ \\
\hline Loyalitas merek $\left(\mathrm{X}_{4}\right)$ & $\begin{array}{ll}\text { 1. } & \text { Komitmen } \\
\text { 2. } & \text { Rekomendasi } \\
\text { 3. } & \text { Kebiasaan memilih } \\
\text { 4. } & \text { Kepuasan }\end{array}$ & $\begin{array}{l}\text { Putra (2013), } \\
\text { Astuti dan Cahyadi } \\
(2007)\end{array}$ \\
\hline Keputusan Pembelian (Y) & $\begin{array}{ll}\text { 1. } & \text { Pertimbangan } \\
\text { 2. } & \text { Prioritas } \\
\text { 3. } & \text { Kecepatan memutuskan } \\
\text { 4. } & \text { Kemudahan memperoleh }\end{array}$ & $\begin{array}{l}\text { Wicaksono(2013), } \\
\text { Astuti dan Cahyadi } \\
\text { (2007), dan Suprapti } \\
\text { (2010) }\end{array}$ \\
\hline
\end{tabular}

Sumber: Data primer diolah, 2017

Kesadaran merek (brand awareness) dihubungkan pada kuatnya kesan yang tersimpan dalam memori yang direfleksikan pada kemapuan pelanggan untuk mengingat kembali atau mengenali kembali sebuah merek di dalam kondisi yang berbeda. Kesadaran merek (brand awareness) dapat dikarakteristikkan menurut kedalaman dan keluasannya. Kedalaman dari kesadaran merek (brand awareness) berhubungan dengan kemungkinan sebuah merek dapat diingat atau dikenali kembali (Nora, 2011). Pengukuran kesadaran merek disesuaikan dari penelitian Humdiana (2005) dan Suprapti (2010). Ada lima indikator pengukurannya, yaitu: 
$\left(\mathrm{X}_{1.1}\right)$ Mengenali merek : Kemampuan untuk mengenali merek Starbucks Coffee, $\left(\mathrm{X}_{1.2}\right)$ Mengingat merek : Kemampuan untuk mengingat merek Starbucks Coffee pada level Top of Mind, $\left(\mathrm{X}_{1.3}\right)$ Ciri khas : Dapat membedakan ciri khas produk Starbucks Coffee dengan produk dari merek lain, $\left(\mathrm{X}_{1.4}\right)$ Mengenali varian : Kemampuan konsumen dalam mengenali varian produk dari Starbucks Coffee.

Kesan kualitas merupakan penilaian konsumen terhadap keunggulan atau superioritas produk secara keseluruhan, persepsi terhadap kualitas keseluruhan suatu produk dapat berpengaruh langsung terhadap keputusan pembelian seorang konsumen serta merupakan persepsi konsumen terhadap keseluruhan kualitas atau keunggulan suatu produk atau jasa layanan berkenaan dengan maksud yang diharapkan konsumen (Negara, dkk 2013). Adapun indikator dari persepsi kualitas menurut Sudarsono dan Kurniawati (2013) adalah $\left(\mathrm{X}_{2.1}\right)$ Kualitas : Persepsi konsumen terhadap kualitas produk Starbucks Coffee dibandingkan dengan merek lain, $\left(\mathrm{X}_{2.2}\right)$ Kehandalan : Persepsi konsumen terhadap kehandalan produk maupun fasilitas dari Starbucks Coffee, $\left(\mathrm{X}_{2.3}\right)$ Daya tahan : Persepsi konsumen mengenai daya tahan kemasan produk (durability) dari Starbucks Coffee.

Menurut Putra (2013) Asosiasi merek merupkan segala sesuatu yang berkaitan secara langsung maupun tidak langsung dengan ingatan konusmen terhadap suatu merek. Terdapat lima indikator pengukuran asosiasi merek disesuaikan dari penelitian Humdiana (2005) dan Kurniawan (2010), yaitu ( $\left.\mathrm{X}_{3.1}\right)$ Manfaat produk : Persepsi konsumen mengenai manfaat mengonsumsi produk Starbucks Coffee, $\left(\mathrm{X}_{3.2}\right)$ Gaya hidup : Kesesuaian Starbucks Coffee terhadap gaya hidup konsumen, $\left(\mathrm{X}_{3.3}\right)$ Kredibilitas : Persepsi konsumen mengenai kredibilitas 
Starbucks Coffee, $\left(\mathrm{X}_{3.4}\right)$ Produk inovatif : Persepsi konsumen mengenai produk Starbucks Coffee yang inovati, $\left(\mathrm{X}_{3.5}\right)$ Citra merek : Pencitraan merek produk di benak konsumen.

Loyalitas merupakan ukuran dari kesetiaan konsumen terhadap suatu merek. Loyalitas merek merupakan inti dari brand equity yang menjadi gagasan sentral dalam pemasaran, karena hal ini merupakan suatu ukuran keterkaitan seorang pelanggan pada sebuah merek (Putra, 2013). Ada empat indikator pengukuran loyalitas merek yang disesuaikan menurut penelitian dari Astuti dan Cahyadi (2007) yaitu $\left(\mathrm{X}_{4.1}\right)$ Komitmen : Komitmen konsumen terhadap Starbucks Coffee, $\left(\mathrm{X}_{4.2}\right)$ Rekomendasi : Persepsi konsumen untuk merekomendasikan Starbucks Coffee kepada pihak lain, $\left(\mathrm{X}_{4.3}\right)$ Kebiasaan memilih : Kebiasaan konsumen dalam memilih Starbucks Coffee sebagai tempat minum kopi, $\left(\mathrm{X}_{4.4}\right)$ Kepuasan : Kepuasan konsumen terhadap produk serta fasilitas dan layanan yang diberikan oleh Starbucks Coffee.

Keputusan pembelian adalah serangkaian unsur-unsur yang mencerminkan keputusan pelanggan apakah akan melakukan pembelian atau tidak (Wicaksono, 2013). Terdapat empat indikator pengukuran keputusan pembelian yang telah disesuaikan menurut Astuti dan Cahyadi (2007) dan Suprapti (2010), yaitu (Y.1) Pertimbangan : Persepsi konsumen dalam mempertimbangkan Starbucks Coffee pada saat memutuskan membeli, $\left(\mathrm{Y}_{1.2}\right)$ Prioritas : Persepsi konsumen dalam menjadikan Starbucks Coffee sebagai prioritas, $\left(\mathrm{Y}_{1.3}\right)$ Kecepatan memutuskan : Kecepatan konsumen dalam memutuskan memilih Starbucks Coffee sebagai 
tempat minum kopi, $\left(\mathrm{Y}_{1.4}\right)$ Kemudahan mendapatkan/memperoleh : kemudahan konsumen untuk menjangkau Starbucks Coffee.

Yang termasuk variabel bebas dalam penelitian ini adalah kesadaran merek $\left(\mathrm{X}_{1}\right)$, persepsi kualitas $\left(\mathrm{X}_{2}\right)$, asosiasi merek $\left(\mathrm{X}_{3}\right)$, dan loyalitas merek $\left(\mathrm{X}_{4}\right)$. Variabel terikat dalam penelitian ini adalah keputusan pembelian (Y). Jenis data yang digunakan dalam penelitian ini adalah data kuantitatif dan kualitatif. Data kuantitatif yang digunakan dalam penelitian ini adalah tabulasi hasil kuisioner yang telah dijawab oleh responden, umur, pekerjaan responden.Sedangkan data kualitatif pada penelitian ini berupa gambaran tentang produk Starbucks Coffee dan pendapat responden terhadap pernyataan yang ada di dalam kuisioner. Sumber data penelitian ini bersumber dari data primer dan sekunder, dimana data primer dalam penelitian ini merupakan responden yang langsung memberikan tanggapan terhadap variabel - variabel penelitian yang akan diuji, dan data sekunder merupakan data yang tidak secara langsung diperoleh dan dikumpulkan oleh peneliti. Data ini dapat diperoleh melalui beberapa alternatif, misalnya dari berbagai media seperti buku, jurnal, arsip, serta dokumen-dokumen yang memiliki kaitan dengan variabel-variabel yang digunakan dalam penelitian.

Penelitian ini mengunakan 100 responden dimana dalam penentuan sampel menggunakan teknik pengumpulan sampel dengan metode non probability sampling. Dalam penelitian untuk memperoleh data yang valid maka jumlah sampel responden yang diambil dan ditentukan paling sedikit 5 sampai 10 kali jumlah indikator (Sugiyono, 2013:130). Sugiyono (2013:163) menyatakan bahwa ukuran sampel yang layak dalam penelitian adalah berkisar 30 sampai dengan 
500. Jadi ukuran sampel sebanyak 100 responden tersebut sudah dianggap layak. Teknik ini merupakan teknik pengumpulan sampel yang menentukan sampel dengan pertimbangan tertentu. Dalam penelitian untuk memperoleh data yang valid maka jumlah sampel responden yang diambil dan ditentukan paling sedikit 5 sampai 10 kali jumlah indikator (Sugiyono, 2013:130). Metode pengumpulan data dalam penenelitian ini adalah dengan metode survey dengan teknik wawancara menggunakan kuisioner. Selanjutnya butir - butir pernyataan diukur dengan skala Likert. Skala ini mengukur sikap, pendapat, dan persepsi seseorang atas sebuah fenomena (Sugiyono, 2013:132).

Adapun kriteria penentuan sampel dalam penelitian ini adalah sebagai berikut: WNI, Usia minimal 17 tahun. Pertimbangan ini digunakan dengan alasan karena pada umur 17 tahun dianggap sudah mampu mengerti isi dari kuisioner dan pada usia ini juga pada umumnya sudah paham mengenai penilaian untuk membandingkan ekuitas dari merek coffee shop tersebut. Customer yang pernah melakukan transaksi di Starbucks Coffee Bali lebih dari sekali. Pertimbangan ini digunakan karena penelitian ini membahas mengenai keputusan pembelian pelanggan.Transaksi dilakukan paling lama dalam kurun waktu tiga bulan terakhir.

Kuesioner terdiri dari pernyataan terbuka dan tertutup. Pernyataan terbuka meliputi nama responden, usia responden, alamat responden, pekerjaan responden, dan lain sebagainya yang memiliki kaitan dengan identitas responden. Pernyataan tertutup merupakan pernyataan yang telah disediakan, dan diberikan 
pilihan jawabannya dalam jumlah yang terbatas.Pernyataan tertutup akan diukur dengan menggunakan skala likert dengan skala 1 sampai dengan 5.

\section{Tabel 2. Pengukuran Data}

\begin{tabular}{cccc}
\hline No. & Pilihan Responden & Kode & Bobot Nilai \\
\hline 1. & Sangat tidak setuju & STS & 1 \\
\hline 2. & Tidak setuju & TS & 2 \\
\hline 3. & Kurang setuju & KS & 3 \\
\hline 4. & Setuju & S & 4 \\
\hline 5. & Sangat setuju & SS & 5 \\
\hline Sumber $:$ Sugiyono (2013) & &
\end{tabular}

Pengujian terhadap hipotesis yang diajukan dilakukan dengan metode regresi berganda. Penelitian ini akan menggunakan alat bantu berupa software statistik yakni SPSS. Analisis regresi berganda digunakan untuk menguji pengaruh dengan menggunakan variabel terikat : Keputusan pembelian, dan variabel bebas Kesadaran merek, Asosiasi merek, Persepsi kualitas, dan Loyalitas merek. Persamaan regresi berganda dalam penelitian ini adalah sebagai berikut:

$$
\mathrm{Y}=\mathrm{a}+\mathrm{b}_{1} \mathrm{X}_{1}+\mathrm{b}_{2} \mathrm{X}_{2}+\mathrm{b}_{3} \mathrm{X}_{3}+\mathrm{b}_{4} \mathrm{X}_{4}+\mathrm{e} \ldots \ldots \ldots \ldots \ldots \ldots \ldots \ldots \ldots \text { (1) }
$$

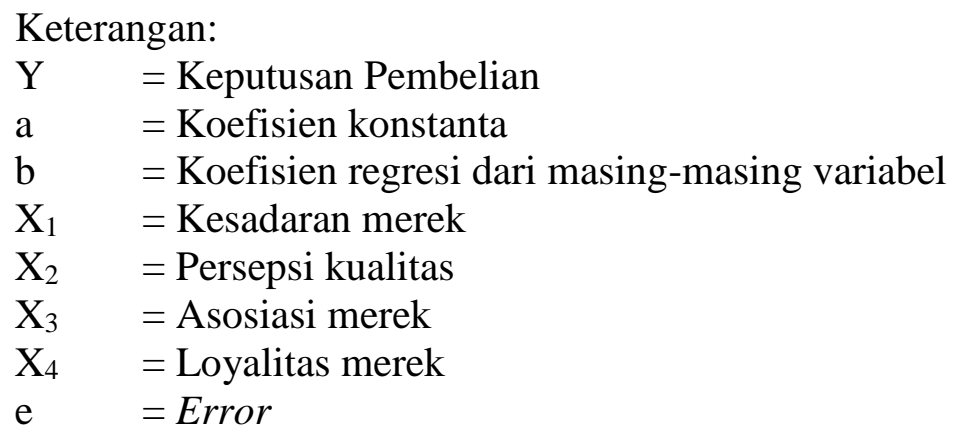

\section{HASIL DAN PEMBAHASAN}

Perhitungan koefisien regresi berganda dilakukan dengan analisis regresi melalui software SPSS, diperoleh hasil yang ditunjukan pada tabel: 
Tabel 3. Hasil Analisis Regresi Linier Berganda

\begin{tabular}{|c|c|c|c|c|c|}
\hline \multirow[b]{2}{*}{ Mod } & & \multicolumn{2}{|c|}{$\begin{array}{l}\text { Unstandardized } \\
\text { Coefficients }\end{array}$} & \multicolumn{2}{|l|}{$\begin{array}{l}\text { Standardized } \\
\text { Coefficients }\end{array}$} \\
\hline & & B & Std. Error & Beta & Sig. \\
\hline \multirow[t]{8}{*}{1} & (Constant) & 2.719 & 1.614 & & .095 \\
\hline & Kesadaran Merek & .283 & .098 & .246 & .005 \\
\hline & Persepsi Kualitas & .355 & .111 & .215 & .002 \\
\hline & Asosiasi Merek & .365 & .086 & .391 & .000 \\
\hline & Loyalitas Merek & .183 & .087 & .164 & .037 \\
\hline & R Square & & 0,633 & & \\
\hline & F Statistik & & 40,951 & & \\
\hline & Signifikansi & & 0,000 & & \\
\hline
\end{tabular}

Sumber : Data primer diolah, 2017

Berdasarkan hasil analisis regresi linier berganda seperti yang disajikan, maka persamaan strukturalnya adalah sebagai berikut :

$\mathrm{Y}=\alpha+\beta_{1} \mathrm{X}_{1}+\beta_{2} \mathrm{X}_{2}+\beta_{3} \mathrm{X}_{3}+\beta_{4} \mathrm{X}_{4}+\mathrm{e}$

$\mathrm{Y}=0,246 \mathrm{X} 1+0,215 \mathrm{X} 2+0,391 \mathrm{X} 3+0,164 \mathrm{X} 4+\mathrm{e}$

Nilai determinasi total sebesar 0,633 mempunyai arti bahwa sebesar 63,3\% variasi Keputusan Pembelian dipengaruhi oleh variasi Kesadaran Merek, Persepsi Kualitas, Asosiasi Merek, dan Loyalitas Merek, sedangkan sisanya sebesar 36,7\% djelaskan oleh faktor lain yang tidak dimasukkan ke dalam model.

Berdasarkan hasil analisis pengaruh kesaaran merek terhadap keputusan pembelian, diperoleh nilai probabilitas signifikansi sebesar 0,005 dengan nilai koefisien beta 0,246 . Hal ini mengindikasikan bahwa kesadaran merek memiliki pengaruh positif terhadap keputusan pembelian. Dimana semakin konsumen menyadari akan keberadaan merek Starbucks Coffee maka semakin tinggi pula keputusan konsumen untuk melakukan pembelian di Starbucks Coffee. Hasil penelitian ini mendukung temuan dari Siali (2016), Akhtar et al (2015), dan 
Winatapradja (2013) yang menemukan hasil bahwa kesadaran merek memiliki pengaruh yang positif terhadap keputusan pembelian.

Berdasarkan hasil analisis pengaruh persepsi kualitas terhadap keputusan pembelian diperoleh nilai Signifikansi sebesar 0,002 dengan nilai koefisien beta 0,215. Ini mengindikasikan bahwa persepsi kualitas memiliki pengaruh positif terhadap keputusan pembelian. Hal ini menunjukan bahwa semakin baik persepsi konsumen mengenai kualitas, terhadap merek Starbucks Coffee maka akan semakin tinggi pula tingkat keputusan konsumen dalam melakukan pembelian di Starbucks Coffee. Penelitian ini mendukung temuan dari Tarmedi dan Penty (2009), Widhiarta (2015), serta Astuti dan Cahyadi (2007) yang menjelaskan persepsi kualitas memiliki pengaruh yang positif terhadap keputusan pembelian.

Berdasarkan hasil analisis pengaruh asosiasi merek terhadap keputusan pembelian diperoleh nilai Signifikansi sebesar 0,000 dengan nilai koefisien beta 0,391. Hal ini mengindikasikan bahwa asosiasi merek memiliki pengaruh positif terhadap keputusan pembelian. Hal ini menunjukan bahwa semakin paham konsumen terhadap asosiasi merek mengenai manfaat, kredibilitas Starbucks Coffee,dan lain-lain maka akan semakin tinggi pula keputusan konsumen dalam melakukan pembelian di Starbucks Coffee. Penelitian ini mendukung temuan dari Winatapradja (2013), Rahendy (2014), dan Fadli dan Qamariah (2008) yang menjelaskan bahwa asosiasi merek memiliki pengaruh positif terhadap keputusan pembelian.

Berdasarkan hasil analisis pengaruh loyalitas merek terhadap keputusan pembelian diperoleh nilai Sig. sebesar 0,037 dengan nilai koefisien beta 0,164 . 
Hal ini mengindikasikan bahwa semakin tinggi tingkat loyalitas konsumen terhadap merek Starbucks Coffee maka akan semakin tinggi pula tingkat keputusan konsumen dalam melakukan keputusan pembelian di gerai Starbucks Coffee. Penelitian ini didukung oleh hasil penelitian Subianto (2013) dan Wijaya (2011) yang menjelaskan bahwa loyalitas merek berpengaruh secara positif dan signifikan terhadap keputusan pembelian.

\section{SIMPULAN DAN SARAN}

Berdasarkan data dan analisis pembahasan yang telah dipaparkan pada bab sebelumnya, maka dapat ditarik kesimpulan sebagai berikut : 1) Hasil uji parsial menunjukan bahwa kesadaran merek, asosiasi merek, persepsi kualitas, dan loyalitas merek secara parsial berpengaruh signifikan terhadap keputusan pembelian, 2) Hasil pengujian simultan menjelaskan bahwa keempat variabel (kesadaran merek, asosiasi merek, persepsi kualitas, dan loyalitas merek) secara bersama-sama berpengaruh terhadap keputusan pembelian. 3) Nilai koefisien regresi pada setiap variabel, dapat dijelaskan bahwa variabel yang paling dominan berpengaruh terhadap keputusan pembelian adalah variabel asosiasi merekyaitu sebesar 0,391 yang memiliki nilai koefisien regresi lebih besar dibandingkan dengan variabel bebas lainnya. 4) Nilai determinasi total sebesar 0,633 mempunyai arti bahwa sebesar 63,3\% variasi keputusan pembelian dipengaruhi oleh variasi kesadaran merek, persepsi kualitas, asosiasi merek, dan loyalitas merek, sedangkan sisanya sebesar $36,7 \%$ djelaskan oleh faktor lain yang tidak dimasukkan ke dalam model. 
Berdasarkan pada kesimpulan di atas, serta dari hasil penelitian dan pembahasan, dapat disarankan beberapa hal sebagai berikut: 1) Starbucks Coffee harus dapat selalu mempertahankan kualitas mutu dan pelayanan dengan tetap mempertahankan tingginya kesadaran konsumen akan merek Starbucks Coffee sehingga akan menimbulkan peningkatan volume penjualan melalui konsumen yang membeli kopi di gerai Starbucks Coffee. 2) Bagi peneliti selanjutnyadiharapkan agar dapat menambah jumlah variabel serta sampel atau responden yang diteliti sehingga dapat mencakup lebih banyak pendapat tentang hal yang mempengaruhi keputusan pembelian suatu merek/perusahaan khususnya merek Starbucks Coffee. 3) Peneliti selanjutnya dapat menggunakan teknik analisa yang beragam, sehingga hasil penelitian dapat dilihat dari berbagai sudut pandang dan berbagai kalangan.

Berdasarkan penelitian yang telah dilakukan, terdapat beberapa hal yang menjadi keterbatasan di dalam penelitian ini. Adapun keterbatasan yang dapat diuraikan, yaitu: 1) Penelitian ini hanya mencari adanya pengaruh kesadaran merek, persepsi kualitas, asosiasi merek, dan loyalitas merek, sedangkan masih banyak faktor-faktor lain seperti harga, lingkungan, dan lain-lain yang dapat mempengaruhi keputusan pembelian. 2) Jumlah sampel yang digunakan masih sangat terbatas, yakni hanya sebesar 100 responden, di sisi lain masyarakat di wilayah Denpasar, Badung, dan sekitarnya sangat lebih dari 100 orang. 3) Masih adanya keterbatasan dalam waktu, tenaga dan biaya yang digunakan di dalam penelitian ini. Hal ini mengakibatkan ruang (cakupan) penelitian masih begitu sempit. 


\section{REFERENSI}

Adriana, Dwi Anggun. 2017. Perbandingan Penilaian Konsumen Terhadap Ekuitas Merek Coffee Shop Di Bandar Lampung (Studi Pada 5 Coffee Shop Di Bandar Lampung). Skripsi. Fakultas Ilmu Sosial dan Ilmu Politik Universitas Lampung.

Akhtar, Naeem., Qurat-Ul-Ain., and Umer Iqbal Siddiqi. 2015. Impact of a Brand Equity on Consumer Purchase Decision in L'Oreal Skincare Products. International Journal Review of Management and Business Research, Vol.5 Issue 3 pp. 178-191

Ahmad, Aqeel., Naveed Ahmad., and Muhammad Nadeem. 2014. The Study Of Brand Credibility And Brand Awareness As Positive Predictors For Brand Loyalty. Arabian Journal of Business and Management Review (Nigerian Chapter) Vol. 2, No. 12 pp.184-207

Asif, Muhammad., Kaleem Abbas, Muhammad Kashif. 2015. Impact of Brand Awareness and Loyalty on Brand Equity. Journal of Marketing and Consumer Research, Vol. 12. Pp. 187-202

Astuti, Sri Wahjuni Dan Cahyadi I Gede, 2007.Pengaruh Elemen Ekuitas Merek Terhadap Rasa Percaya Diri Pelanggan Di Surabaya Atas Keputusan Pembelian Sepeda Motor Honda. Dalam Majalah Ekonomi, 17(2), h: 145156.

Bastian, D.A.. 2014. Analisa Pegaruh Citra Merek (Brand Image) dan Kepercayaan Merek (Brand Trust) Terhadap Loyalitas Merek (Brand Loyalty) ADES PT. Ades Alfindo Putra Setia. Jurnal Manajemen Pemasaran Petra. Volume 2, No. 1, pp. 1-9.

Chen, Tser-Yieth., Tsai-Lien Yeh, and Wun-Sin Jheng. 2013. Factors influencing brand association. African Journal of Business Management, Vol. 7(9), pp. 114-126.

Daftar Kedai dan Kafe di Denpasar 2016 www.disparda.baliprov.go.id (diakses pada Tanggal 13, Bulan Februari, Tahun 2017).

Darmawan, Syarifah Hudayah, Asnawati. 2016. Perbandingan Ekuitas Merek Indomie Dan Mie Sedaap. Jurnal Manajemen Universitas Mulawarman Vol. 8 (2) pp. 113-135

Doostar, Mohammad., Maryam, K., dan Reza, K. 2012. Impact of Brand Equity on Purchase Decision of Final Consumer Focusing on Product with Low 
Mental Conflict. Journal of Basic and Apllied Scientiffic Research, 2(10): 10137-10144.

Fadli, Dan Qamariah. 2008. Analisis Pengaruh Faktor-Faktor Ekuitas Merek Sepeda Motor Merek Honda Terhadap Keputusan Pembelian Konsumen. Jurnal Manajemen Bisnis Volume 1, No. 02, pp.48-58.

Fayrene Y.L. Chieng, and Goi Chai Lee. 2011. Customer-Based Brand Equity: A Literature Review. Journal of Arts Science \& Commerce, 2(1), pp: 33-42.

Firdaus, Tidar Rabbani. 2015. Pengaruh Ekuitas Merek Terhadap Keputusan Pembelian (Studi Di Warung Kopi Cak Wang Jember). Skripsi. Fakultas Ilmu Sosial dan Ilmu Politik Universitas Jember

Fouladivanda, F., M. A. Pashandi, A. Hooman, dan Z. Khanmohammadi. 2013. The effect of Brand Equity on Consumer Buying Behavior in term of FMCG in Iran. Interdisciplinary Journal of Contem- porary Research in Business 4(9): 945-957.

French, A. \& Smith, G., 2013.Measuring Brand Association Strength: A Consumer Based Brand Equity Approach. European Journal Of Marketing, 47 (8), pp. 1-20.

Kartajaya, H. 2010. Brand Operation, The Official MIM ( Markplus Institute of Marketing) Academy coursebook. Jakarta: Esensi Erlangga.

Kasali, Rhenald. (2010). Manajemen Public Relations: Konsep dan Aplikasinya di Indonesia.Jakarta: PT. Pusaka Utama Grafiti.

Lee, G. C \& Leh, F. C. Y. 2011. Dimensions of Customer -Based Brand Equity: A Study on Malaysian Brands. Journal of Marketing Research and Case Study, pp. 1-1

Malik, Muhammad E., Muhammad M.G., Hafiz. 2013. Importance of Brand Awareness and Brand Loyalty in assessing Purchase Intentions of Consumer. International Journal of Business and Social Science, Vol. 4 No. 5, pp. 206-225

Miftakh, Isro' Jimmi. 2013. Pengaruh Kesadaran Merek, Persepsi Kualitas Dan Loyalitas Merek Terhadap Keputusan Pembelian Handphone Blackberry. Skripsi. Fakultas Ekonomi Universitas Diponegoro Semarang

Moradi, H \& Zarei, A. 2011. The Impact of Brand Equity on Purchase Intention and Brand PreferenceThe Moderating Effect of Country of Origin Image. Australian Journal Image and Apllied Sciences. Vol. 5, No. 3, pp: 539-549 
Muzaqqi, Aim., Achmad Fauzi., Imam Suyadi. 2016. Pengaruh Kesadaran Merek, Kesan Kualitas, Asosiasi Merek Dan Loyalitas Merek Terhadap Ekuitas Merek (Survei Pada Konsumen Pembeli Dan Pengguna Produk Sari Apel Siiplah Di Perumahan Saxophone Kecamatan Lowokwaru Kota Malang). Jurnal Administrasi Bisnis Brawijaya Vol. 31 No. 1, pp. 1-9

Negara, Intan Ratu Perwira., Imam Suyadi, Sunarti. 2013. Asosiasi VariabelVariabel Kesadaran Merek, Asosiasi Merek, Persepsi Kualitas, Loyalitas Merek. Jurnal Administrasi Bisnis Universitas Brawijaya Malang, Vol. 5 no.1 pp.1-12

Nigam \& Kausik, R. 2011. Impact of Brand Equity on Customer Purchase Decisions An Empirical Investigation with Special Reference to Hatchback Car Owners in Central Haryana. International Journal of Computational and Management. Vol. 12.

Nitisusastro, Mulyadi 2012, Perilaku Konsumen dalam Perspektif Kewirausahaan, Bandung : Alfabeta.

Norouzi, Abdollah., dan Bahman, Fallah. H. 2011. The Effects of Brand's Country of Origin Image on The Formation of Brand Equity. Australian Journal of Basic and Applied Sciences, 5(12): 766-770.

Nursanti, Ony Novita. 2017. Pengaruh Ekuitas Merek Terhadap Keputusan Pembelian Paket Internet 3 (Tri). Jurnal Manajemen Fakultas Ekonomi Universitas Muhammadiyah Yogyakarta, pp. 1-20

Putra, Rendy Pratama. 2014. Analisis Penilaian Konsumen Untuk Mengukur Ekuitas Merek Pada Pengunjung Starbucks Coffee, Excelso Coffee, dan Ngopi Doeloe Di Kota Bandung. Jurnal Institut Manajemen Telkom Bandung, pp. 1-20

Rahendy, Arief. 2014. Pengaruh Ekuitas Merek Terhadap Keputusan Pembelian Handphone Samsung Android. Jurnal Ilmu \& Riset Manajemen Vol. 3 No. 4 (2014) pp.1-17

Sari, Mela Hardika. 2016. Pengaruh Ekuitas Merek (Brand Equity) Android Samsung Terhadap Minat Membeli Pada Mahasiswa Fakultas Psikologi Universitas Islam Negeri Malang. Skripsi. Fakultas Psikologi Universitas Islam Negeri Maulana Malik Ibrahim Malang.

Sejarah Starbucks Coffee www.wikipedia.org/wiki/starbucks, (diakses pada Tanggal 13, Bulan Februari, Tahun 2017).

Siali, Fadilah., Pang Jiayi., and Mahani Mohammad A.S. 2016. Relationship Between Brand Equity And Consumer Purchase Decision: A Case Of An 
International Brand Of Footwear. International Journal of Service Management and Sustainability (IJSMS), Vol. 1 No. 1 pp.58-74

Subianto, R. Adi. 2013. Pengaruh Elemen Ekuitas Merek Terhadap Rasa Percaya Diri Pelanggan Di Semarang Atas Keputusan Pembelian Ponsel Sony Ericsson.JurnalEkonomi dan Bisnis Dian Nuswantoro, Vol. 5, pp-65-77

Sugiyono. 2013. Metode Penelitian Bisnis. Bandung: Penerbit Alfabeta.

Suharyani, Komang. 2015. Pengaruh Ekuitas Merek Terhadap Keputusan Pembelian Produk Minuman Teh Botol Sosro Pada Mahasiswa Jurusan Pendidikan Ekonomi Undiksha 2015. Jurnal Jurusan Pendidikan Ekonomi (JJPE) Volume: 5 Nomor: 1, pp. 1-13

Tarmedi, Eddy dan Penty Nur Asri. 2009. Pengaruh Perceived Quality Dari Brand Equity Terhadap Keputusan Pembelian Deterjen Bukrim (Survei Pada Konsumen Di Giant Supermarket, Griya Setyabudhi, Dan Isola Swalayan Di Bandung). Jurnal Pendidikan Manajemen Bisnis, Vol.8 no. 15 pp.1-23

Wang, Jin. 2015. The relationship between brand association and brand equity in the brand relationship management. Journal of Arts and social Science, Vol. 4(1) pp. 1-6.

Widhiarta, Teguh Esa IGN. 2015. Pengaruh Ekuitas Merek Terhadap Keputusan Pembelian Iphone Di Denpasar. E-Jurnal Manajemen Unud, Vol. 4, No. 4 pp. $832-848$

Wijaya, Dimas Surya. 2011. Analisis Pengaruh Ekuitas Merek Terhadap Keputusan Pembelian Handphone Blackberry (Studi Kasus Pada Mahasiswa Fakultas Ekonomi Universitas Diponegoro Semarang). Skripsi.Fakultas Ekonomi Universitas Diponegoro.

Winatapradja, N. 2013.Ekuitas Merek Pengaruhnya Terhadap Keputusan Pembelian Produk Donat J.co Donuts \& Coffee Di Manado Town Square.Jurnal EMBA, 1(3), pp: 958-968.

Yaseen, N., Tahira, M., Gulzar, A \& Anwar, A. 2011. Impact of Brand Awareness, Perceived Quality, and Customer Loyalty on Brand Profitability and Purchase Intention: A Reseller's View. Interdisciplinary Journal of Contemporary Research in Business, Vol. 3, No. 8, pp. 833-839 